\title{
The perfect lie: Sandee Chan and lesbian representability in Mandarin pop music
}

\author{
Fran MARTIN
}

I don't know who's right

I only know none of them are like me.

They don't ask as much as I do

They don't think as long as I do

They don't wait as patiently as I do

To discover everything is wrong

Depending on how you say it.

If you love me, I beg you: tell me.

Tell the perfect lie

To move me.

If you love me, I beg you: tell me.

Tell a serious lie,

Make up the perfect excuse.

The whole world is right

Not like me.

The whole world is right

I'm the one who's wrong.

The whole world is fake.

I'm just scared you'll say

You don't love me, because it is I who am wrong.

Because it is I who am wrong, say you don't love me.

- Sandee Chan, "Perfect"

This epigraph is a translation of the lyrics of the Mandarin pop song "Perfect" (Wanmei) written and performed by Taiwanese singer-songwriter Sandee Chan (Chen Shanni) for her 2000 album Perfect moan. That album, like her previous five and her most recent one (Happy Birthday! music543, 2002) has proven popular with young lesbian (nütongzhi) ${ }^{1}$ audiences in Taiwan, despite the fact that Sandee herself does not identify as a lesbian and has at times expressed an ambivalent attitude toward her own queer fame. In this paper, Sandee's music is positioned as an example of Mandarin pop, which I argue constitutes a significant musical form within both global and Asia-Pacific regional circuits of pop music production and consumption today. The paper then considers Sandee's popularity with the emergent public designated by the neologism nütongzhi, a sexual category that is arguably a hybrid one produced out of a dialogue between local conditions in Taiwan and the transnationally mobile Euro-American category "lesbian." In this sense, the paper's analytic framework is implicitly global: it presumes both the importance of recognizing the place of Mandarin pop among global music cultures, and the need to take account of non-Euro-American, locally specific but regionally and globally imbricated formations of sexuality like nütongzhi.

Framed by this understanding of recent transformations in musical and sexual cultures as 
a function of globalization, the paper situates Sandee's music within the local context of its production and consumption in Taiwan and works toward a "microscopic" perspective on experiences of the music by nütongzhi fans. In particular, it asks about a possible relationship between how nütongxinglian (female homosexuality) is spoken (or unspoken) in Sandee's music, and the conditions of nütongxinglian representability within Taiwan's contemporary public culture more broadly. The paper considers both the rhetorical figuration of nütongxinglian as subtextual reticence in the texts of Sandee's song lyrics and music videos, and the activity of Sandee's nütongzhi fans who find material here for the elaboration of oppositional meanings. Such a hybrid methodology - a combination of textual analysis and fan ethnography represents the union of two approaches whose conceptual bases are sometimes taken to be discontinuous or incommensurable, if not opposed. The 1990s high moment of "queer theory," for example, was frequently criticized for its supposedly narrow emphasis on the textual at the expense of the more broadly social (Seidman 1995). While one might respond effectively to this charge with the observation that representation is nothing if not thoroughly social, historical, and political, nevertheless it is instructive to combine the insights garnered through textualist close-reading strategies with understandings of the lived consumption of texts by their audiences. Such a combination of approaches also underscores the fact that the textual is certainly not the opposite of the everyday: interpretation is itself an everyday activity, and perhaps particularly in the case of the ubiquitous, quotidian, yet often hermeneutically complex phenomenon of pop music.

Consideration of these two aspects in relation to Sandee's music suggests that the representation and experience of nütongxinglian in contemporary Taiwan is structured around a particular kind of ambivalent reticence. ${ }^{2}$ As has been shown, reticence on tongxinglian (homosexuality) is frequently the product of the disciplinary limitations enforced on tongzhi representation by homophobic forms of cultural power. Nonetheless, I will argue that the particular form of lesbian reticence Sandee's star image and musical output encode offers points of purchase for nütongzhi to elaborate oppositional meanings that function by exploiting the potential ambivalence of reticence as a mode of representation.

Taiwan is recognized as the world center of the Chinese music industry. Taiwan-produced Mandarin pop music had eclipsed Hong Kong-produced Cantopop in global sales by 1999 (Wong 1999), and the island is the largest producer of Mandarin pop and constitutes the world's most valuable Chinese music market by a wide margin. ${ }^{3}$ At the level of consumption, too, Mandarin pop is a central part of the experiential landscape of everyday life in Taiwan. For its fans, it is the site of significant modes of public sociality - in concerts, live shows, and the massively popular karaoke bars - as well as enabling private moments of introspection and absention in the concentrated individual activity of ting yinyue (listening to music), be it through a Walkman or Discman in the public space of the street, or a stereo system in the private spaces of home or car. Even for those who don't actively seek it out, pop's pervasiveness in the everyday scenes of Taiwan's late capitalist commodity culture makes it impossible to avoid: Chinese-language pop plays non-stop in convenience stores, supermarkets, streetmarkets, and other shops; on taxi and bus radios; in restaurants and bars; and along with music videos or as televised live performance on cable and free-to-air TV.

But despite its obvious significance in relation to both the global music industry and the everyday life experience of its audiences, Taiwan-produced Mandarin pop has to date received scant attention in English-language cultural criticism. ${ }^{4}$ When Chinese pop music is discussed, it is almost always framed by questions about the nation, national belonging, and postcolonial resistance to the hegemony of the Mandarin language, or political dissidence within the PRC state (Witzleben 1999; Gold 1993; Chen n.d.). ${ }^{5}$ There are good reasons for taking this approach, particularly in the case of Cantopop in Hong Kong, Taiyuge in Taiwan, and Mandarin protest music like that of Cui Jian in late-'80s mainland China. But to date this focus has all but precluded attention to other questions about the micro-politics of Chinese language pop 
music consumption, such as questions about the relationship between music consumption and individual sexual identification: the focus of this paper.

In one of the best-known instances of English-language cultural criticism of Chinese pop, Rey Chow (1993) cites the lyrics of Taiwanese singer Luo Dayou's song, "Comrade lover," as an epigraph for her argument on popular music's subversive potential in allowing its listeners the "freedom to be deaf to the loudspeakers of [PRC] history" (Chow 1993: 163). Luo's music undeniably represents a good example of popular music as political protest against the rhetorical and actual violence of the PRC state. Interestingly, though, queer listeners' appropriations of Luo's song underline in an exemplary manner the necessary partiality of Chow's nation-based analytic framework. Taiwan's tongzhi cultures have appropriated the title of Luo's song "Comrade lover" (Airen tongzhi) as a kind of queer code, due to the title's resonance with the sexual politics that coalesces under the term "comrade" (tongzhi). The phrase airen tongzhi and the variant tongzhi airen have appeared in the titles of a range of queer-themed books, radio programs, social groups and web sites based in Taiwan. ${ }^{6}$ As a form of coercive power, heterosexism in contemporary Chinese societies is not the effect of state oppression alone; similarly, popular music encodes and enables resistance not only to the power of the state qua state but to other forms of cultural power as well, including heterosexism and homophobia.

In the lyrics of "Perfect" can be heard an interesting meditation on the conditions of representability of the nütongzhi subject in contemporary Taiwan. As well as foregrounding the singer's quandary vis-à-vis an implied question of sexual morality, the lyrics figure her feeling of isolation and of unsettling difference from others. Moreover, the lyrics, with their plays on hermeneutic uncertainty and the tension between truth and falsehood; knowing and unknowing can be read as an apposite representation of the infamously tortuous relationship between homosexuality and representation itself. The song's refrain is organized around a plea for a hitherto reticent love to speak forth; a plea immediately complicated by the admission that any straightforward confession of this love is impossible: once spoken, the love is disavowed as a "lie." To a listener attuned to queer subtext, the lie and the excuse that the singer begs to be told might suggest that her interlocutor is reluctant to tell the truth of this love as a result of the enunciatory constraints of the closet. Perhaps the singer yearns for her lover's lie because this lie, a kind of reticent telling, might betoken a love not fully speakable, thus being preferable to her continuing, unbearable silence.

As suggested by its popularity with lesbian audiences in Taiwan and beyond, the song's music video lends itself similarly to lesbian interpretation. ${ }^{7}$ Sandee's coolly melancholy minorkey melody provides the soundtrack to a loose narrative involving three characters. Sandee, playing acoustic guitar and singing, follows a man and woman at a distance through a series of deserted urban locations. The camera cuts constantly back and forth in point-of-view shots between Sandee and the couple, with the look frequently exchanged between Sandee and the other woman. Toward the end of the video the camera focuses almost exclusively on Sandee and the woman. There is a cross-cutting sequence that deploys eyeline matches to suggest that the two women are lying on the grass with Sandee gazing at the other woman, until the man re-enters the frame and stands over the other woman, gazing down at her. Finally, we watch the other woman walking up a staircase accompanied by the man, ascending away from Sandee. Such a clip might be interpreted, innocuously enough, as being about Sandee's longing for the other woman's boyfriend, and indeed there are elements in the video to suggest such a reading. ${ }^{8}$ Its queer potential, though, lies in its refusal to close off the possibility that it's the other woman, not the man, to whom Sandee addresses her song and for whose love, lie and excuse she begs. ${ }^{9}$

The shadowy lesbian presence that haunts this video, as well as other elements of Sandee's public self-representation like the album cover of her 1994 CD, Four seasons [FIGURE 1], mirror the ambiguities of Sandee's own star persona. It may, in a sense, seem perverse to search for nütongzhi significance in the songs of a married singer who has publicly said, with crashing 


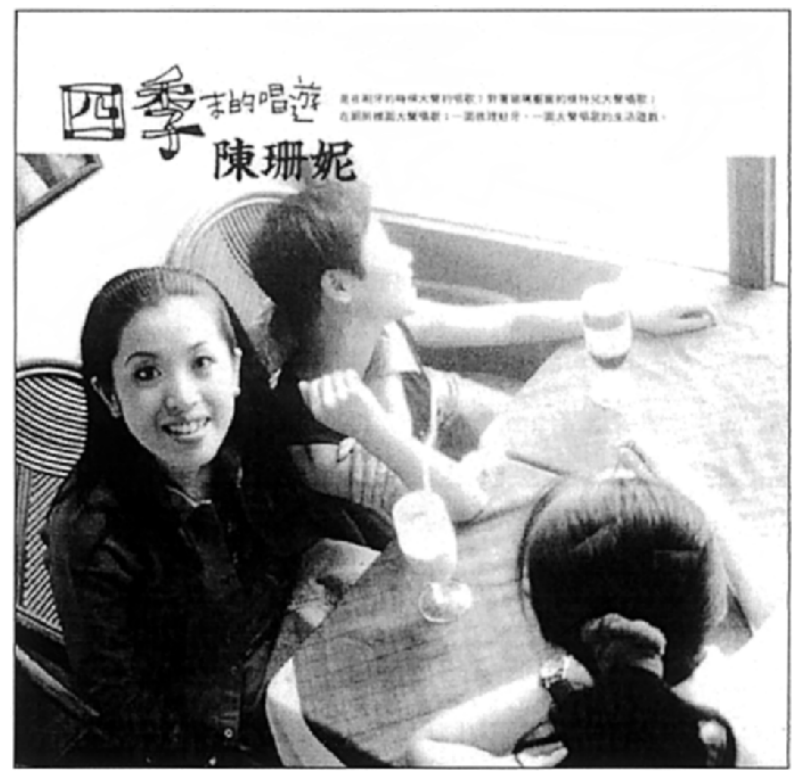

Figure 1. Album cover for Four seasons, Sandee Chan, Friendly Dogs, 1994. Sandee's arm is thrown about the shoulders of a short-haired woman who looks away from the camera: the pairing of the two perhaps suggests a hint of T/po (comparable to butch/femme) lesbian style.

(Copyright: BeFun Cooperation)

ambivalence, that she doesn't mind lesbian fans "as long as they don't harass me" (Gaystation n.d. b). Yet in March 2001 Hong Kong's gay lifestyle website, Gaystation.com.hk, called Sandee "Taiwan's latest gay icon," and in a webcast interview with Gaystation Sandee confirmed that large numbers of nütongzhi fans have regularly attended her shows since the early '90s, and frequently appear backstage to give her gifts and speak with her - though she admits to a slight, but not hostile puzzlement at the prominence of this nütongzhi fan-base. In 1999, Sandee sang at a benefit gig for the Tongzhi Hotline, a Taipei tongzhi activist organization, and guest-starred as cover girl for the lesbian and gay glossy magazine GEL (GEL April 1999, Tongzhi Hotline, n.d.). Although some of Sandee's nütongzhi fans who filled out questionnaires for this project told me they'd never considered a direct link between Sandee and the topic of nütongzhi, one woman said she considered Sandee a "straight queer" (zhi tongzhi) due to her support of tongzhi politics, while another said she'd heard it rumored that Sandee was bisexual and so considered her a "celebrity [female] queer" (nütong mingren). In this sense, Sandee's star image itself encodes the same ambiguous representation of lesbianism that can be read in some of her lyrics, music videos, and album covers: on one reading, both Sandee and her musical output appear unremarkably straight; on another reading, despite this ostensible straightness, Sandee and her music index the penumbral presence of queerer possibilities.

Lesbian and gay studies scholars have written at length of the ways in which the myriad practices of homosexual closeting produce homosexuality in Euro-American modernity as locked in an intractable, discomforting embrace with questions about visibility and representation. In The apparitional lesbian, Terry Castle traces the historical trajectory which has seen the figure of the lesbian in modern Euro-American literature and culture come to bear an even more troubled relationship to visibility than that of the gay man, so that the lesbian becomes "a kind of 'ghost effect' in the cinema world of modern life" (Castle 1993: 2). Comparably, but 
also differently, representations of tongxinglian in Taiwan have frequently made it a shadowy subject ruo yin ruo xian: now hidden; now disclosed, flickering at the margins of cultural life (Martin 2000).

Related to these arguments is Jenpeng Liu and Naifei Ding's discussion of the relationship between tongxinglian and hanxu: a classical term relating primarily to speech, that has been translated variously as "holding back," "storing up," "conservation," "reserve," "potentiality" and "concealed and implied," and which the authors style "reticence" (Liu and Ding 1998: 115). Liu and Ding's article "Reticent poetics, queer politics" is a critique of a recent tendency in Hong Kong and Taiwan to cast the public avowal of a non-straight sexual identity as antithetical to "Chinese culture," which according to some is characterized by a tradition of "silent tolerance" toward non-straight sexualities. Liu and Ding argue that the privileging of hanxu in this "silent tolerance" model makes life unbearable for Chinese tongzhi who, according to the social system that values this effectively homophobic reticence on the subject of non-straight sexuality, must not publicly avow a tongzhi identity. Given all this, is there a kind of reticence to be read in the equivocal voicing of female homoeroticism by Sandee Chan and other Mandarin pop singers? What relation might their eloquent allusions to this subject bear to the homophobic, disciplinary force of the hanxu identified by Liu and Ding? In what follows, I hope to formulate a preliminary response to these questions.

In the 1990s, available models for representing tongxinglian in Taiwan underwent an unprecedented transformation. In the early '90s existing same-sex bar and cruising subcultures were joined by a public tongzhi movement that appeared in northern Taiwan initially as part of the proliferation of grass-roots social movements following the lifting of martial law in 1987. This new culture produced tongzhi identities that might be interpreted in terms of glocalization, in this case the local selective appropriation, re-working and critical interrogation of globally mobile lesbian and gay imaginaries (Martin 1999; Chi 1997). As well as the rise of a lively tongzhi activist movement, the decade also saw a stunning boom in tongzhi literature (Martin 2003). A number of queer-themed films were made by Ang Lee, Tsai Ming-liang, Mickey Chen, Li Xiangru, and a new generation of young, independent and experimental tongzhi filmmakers. At the same time, courses in lesbian and gay studies were established at some of the island's universities, and there was an efflorescence of tongzhi subcultures centered around social groups, bars, dance clubs, and the Internet. ${ }^{10}$

All this brought nütongxinglian into public circulation in a number of new ways. The consolidation of the category of nütongzhi as a substantial, recognizable identity, however, also catalyzed a more organized homophobic backlash. Throughout the '90s local lesbian communities were plagued by sensationalistic journalism that strove, often successfully, to render the lesbian subject literally and injuriously visible. In 1992, for example, the TTV World News Report ran a hidden-camera story on a $\mathrm{T}$ bar (lesbian bar) together with an interview with Mandarin pop superstar Pan Meichen, who favors a rather butch style of self-presentation. The effect was to insinuate that Pan was herself a lesbian, a charge which she strenuously denied (Pizi n.d.). But in a paradoxical about-face following the Pan Meichen scandal - illustrating Chang Hsiao-hung's (1998) argument about the ambivalent homophobia/homophilia of Taiwan's public culture - in 2000, TTV began broadcasting the island's (and surely the region's) first domestically produced, free-to-air, lesbian-themed, prime-time weekly TV drama series: Rebel daughter (Niniu), based on Du Xiulan's popular 1996 novel of the same title. In music culture, the 1990s moment of nütongzhi visibility correlates with the formation of underground bands including Bang-bang Mang and T-Time, which offered a performance of nütongzhi identity along with their nütongzhi-themed songs at small, local bars for a primarily nütongzhi audience (Parry 2000 and 2001). Amie Parry characterizes this underground nütongzhi music subculture as a counterculture: not only different from mainstream pop music, but outspokenly critical of the heterosexist culture that sustains it (Parry 2000). In the above ways, then, a nascent queer public sphere emerged in Taipei in the '90s. These events enabled a new mode of representation of 
tongxinglian: a mode characterized by the denotation of the subject as an identity to be claimed with pride; an identity lent weight and dignity by the struggles of the tongzhi movement to make tongzhi and nütongzhi livable options within local contexts.

However, alongside the emergent modes of public representation and counter-cultural self-representation enabled by the tongzhi movement there continues to flourish another mode of nütongxinglian representation. Rather than being proudly denoted in association with the alternative sphere of nütongzhi subculture, this form of representation manifests as encoded subtext within popular entertainment cultures. While in one sense an older mode of representation, this production of nütongxinglian as encoded subtext is also in part enabled by the new visibility of transgressive sexualities: out-and-proud denotation and equivocal connotation come, in Taiwan's contemporary public culture, to work alongside each other and interpenetrate in new and interesting ways. For example, it is likely to be precisely the new public visibility of nütongzhi culture and desire, effected by the efforts of nütongzhi activists, authors, and public figures, which enables the kind of casual, up-beat reference to lesbian desire that is heard in Sandee's pop song, "Beautiful girl," discussed below.

In one way, the subtexting of nütongxinglian in Taiwan's public culture echoes homosexuality's inhabitation of Euro-American film and music cultures. For example, the essays collected in the "Dossier on popular music" in Corey Creekmur and Alexander Doty's anthology, Out in culture (1995) highlight the role of queer subtext and differential decoding by lesbian and gay audiences of popular music (Creekmur 1995; Dyer 1995; Stein 1995). Arlene Stein (1995) has discussed the complexities of lesbian representation in music, where on the one hand the outness of a lesbian artist can endanger the commercial viability of her work, and on the other contemporary pop music culture voraciously absorbs particular kinds of representations of lesbianism (Stein 1995: 421). Stein argues that this leads to a situation in which lesbian style in pop music becomes "a series of floating signifiers" and lesbian meaning is available, for the most part, only as ambiguity due to an effective "prohibition against 'speaking' lesbianism" (Stein 1995: 421, 422; emphasis added). But this reticent representation is not without its productive side, since it "allows audience members to listen to music which they consider, secretly, to be lesbian, with the knowledge that millions of other people are also listening to it" (Stein 1995: 423). It is a similar ambivalent, infiltrating lesbian potentiality that I want to consider in relation to the consumption of Sandee Chan's music, while remaining attentive also to the specificities of the music's local context.

Mandarin pop music's mode of lesbian representation, like that which Stein identifies in English-language pop, is characterized by ambiguity, connotation and subtext. As is the case with Euro-American queer readings of film and pop stars, tongzhi pleasure in the queer potential of popular cultural icons depends on the mechanisms of rumor, gossip and fantasy enabled by forms of tongzhi subcultural sociality, for example in tongzhi friendship circles, social organizations, and cultures of consumption (Bradby 1993; Becker et al 1995). In recent years, too, the Internet has become a significant medium for the dissemination of queer star gossip among tongzhi music fans across Taiwan, Hong Kong, and Chinese diasporas. ${ }^{11}$ But while there are many similarities between queer subtexting in Euro-American popular culture and in Taiwan, in what follows I want to consider how the subtextual representation of nütongxinglian works in relation to the specific enunciatory regime of reticence (hanxu) which Liu and Ding show constitutes a pervasive representational structure demarcating the place of tongxinglian within the contemporary cultures of Taiwan and Hong Kong. ${ }^{12}$

An example of tongzhi developing queer readings of ostensibly "straight" entertainment culture has been discussed in detail by Chang Hsiao-hung (1998). In 1996 the Tongzhi Space Alliance, lobbying the Taipei City Government over the proposed redevelopment of Taipei New Park, which is a historical site of male tongxinglian cruising and collective memory, organized the "10 great tongzhi lovers vote." Lists were compiled of twenty male and twenty female candidates for which tongzhi participants were asked to vote in order of preference as 
"dream lovers," and the vote was publicized as part of a series of activities aimed at drawing attention to tongzhi culture in the service of saving New Park. Names on the "Nütongzhi dream lover list" were drawn from all three levels of local Taiwanese, transnational Chinese, and global popular cultural scenes, and included among others Qian Weijuan, national basketball star; Yang Lihua, star of koa'a hi local Taiwanese opera; Hong Kong actress Anita Yuen and singer/actress Vivian Chow; Tracy Huang, Lin Liangle, Pan Meichen and Faye Wong, all Taiwan or Hong Kong-based pop singers; as well as Winona Ryder, Geena Davis and Drew Barrymore (Tongzhi Space Alliance 1996). Chang argues that this activity constitutes a "queering" of popular culture itself as tongzhi voters reveal the latent tongzhi subtext of the popular star images.

The site within Taiwan popular music culture that has most frequently been the subject of scholarly lesbian subtextual analysis is local singer Li Yijun's 1993 rendition of the Minnan song, "Dragon Goddess in a bitter sea" (Kho hai lu sim liong) (Chao 1996: 63-66; Jian 1997: 99-101; Lu 1994). ${ }^{13}$ The song was originally written as the theme for a popular 1970s midday TV show based on Taiwanese puppet theatre (budai xi) and was re-interpreted years later by $\mathrm{Li}$ Yijun, a singer who in Jian Jia-shin's words "both in voice and image suggests a savor of urbane androgyny" (Jian 1997: 100). The song was widely celebrated by feminist scholars as "Taiwan's first mainstream lesbian song" (Chao 1996: 64). For example, Issue 2 of the nütongzhi 'zine $A i$ $B a o$, produced by graduate students at National Taiwan University, featured on the cover an artist's rendition of the avenging Dragon Goddess accompanied by an excerpt from the song's lyrics:

Hating making boyfriends

Welcoming girlfriends

The Dragon Goddess is adrift in the bitter sea of a strange land.

I'm not a young lady

What I am is a vixen.

Merciless circumstance forces me down to the city of darkness.

("Dragon Goddess" 1994, my translation)

Drawing on the work of John Fiske and Ien Ang on appropriation and the active audience, $\mathrm{Lu}$ Mei suggests in an article in the same issue of $A i B a o$ that in the context of being sung in a $T$ bar this song accrues an obvious subtext of nütongzhi significance. Lu argues that the song is amenable to nütongzhi interpretation due to its suggestion of gender transgression and its figuration of the Dragon Goddess's loneliness and isolation, and can be read as a critique of the heteronormative society that causes the Dragon Goddess's (read: nütongzhi's) oppression, forcing her down into the "city of darkness" (Lu 1994: 13-14). Equally, perhaps, the "city of darkness" into which the Dragon Goddess is forced might be understood as a self-reflexive figuration of the connotative level of signification to which the subject of nütongxinglian is banished both by the song itself, and by Taiwan's popular music culture in general.

As a contemporary instance of a lesbian queering of popular music and one that pertains to Mandarin rather than Minnan music, Sandee Chan provides an interesting site for analysis. While her "alternative" music has never met with the degree of popular success achieved by Li Yijun's chart-topping cover of "Dragon Goddess," Sandee's music achieves far wider exposure than the countercultural nütongzhi bands. In a sense, Sandee occupies a liminal position between the mass market of Top 40 pop and the underground music scene, managing to sustain popularity with her considerable nütongzhi fan base while also achieving good album sales and radio airplay.

As a component of my investigation into Sandee Chan's lesbian significance, in 2000-2001 I posted calls at a number of Chinese-language lesbian Internet and BBS sites for volunteer 
self-identifying nütongzhi Sandee fans to fill out questionnaires on their fandom. ${ }^{14}$ Resulting from these calls I received responses from eighteen nütongzhi fans and fully completed questionnaires from ten of those. All ten of the fully completed questionnaires came from Taiwan. Clearly, this sample is too small to draw quantitative conclusions about the nature of Sandee's nütongzhi fan-base, and the aim of my project is rather to make a qualitative study of the responses of Sandee's nütongzhi fans. However, the limits of the sample of respondents must be emphasized. Most importantly, since the calls for respondents were posted on the Internet, largely at BBS sites on university servers, it can be assumed that the majority of respondents are either students or young white-collar workers with the knowledge, leisure and resources to spend time socializing in these nütongzhi cyberspaces (Berry and Martin, 2003).

Born in Shanghai, Sandee Chan now lives and works in Taiwan. She has to date produced seven albums, the first five of which were released with Friendly Dogs, an independent label specializing in local artists. But for her 2000 album, Perfect moan, Sandee signed with Magic Stone: a subsidiary of the sprawling, trans-Asian Rock Music Group, South-East Asia's largest independent record company (Wong 1998). Sandee has also written a book of fiction, numerous works of poetry, and several musical scores for theatre. She has been involved in arranging scores for recent Hong Kong films including Wong Kar-wai's In the mood for love and Tsui Hark's Time and tide, and frequently writes music for other Mandarin pop singers. One Internet fan site for Chan introduces her with these words:

In most people's impression, "famous Taiwanese singer" and "commercial distribution and packaging" are practically synonymous. Only Sandee Chan is different. Sandee Chan is not a product of Taiwan's pop music scene. Rather, she is a music worker who has become a creative singer and producer by means of her own talents.

(Anonymous n.d.)

As this excerpt suggests, Sandee's music is often constructed, both in the discourses of her fans and in the promotional material of her record companies, as "independent" and "alternative." Sandee's musical output, with its hints rough-edged "band sound" makes her part of a movement in Taiwan Mandarin music since the mid '90s that sets itself up in self-conscious opposition to the studio produced, sentimental love songs that have till now dominated the charts both in Taiwan and throughout the global scene of Chinese pop. These new Taiwan musicians also differ from their predecessors in that they tend to perform live far more frequently, and in that many of them (including Sandee) are singer-songwriters, unlike most stars of Cantopop or earlier forms of Mandarin pop.

Responses from Sandee's nütongzhi fans to a question about what other music they like offers an interesting map of what might be called a particular (urban, well-educated) "nütongzhi taste public" that selects largely independent, largely female artists from the three levels of Taiwan local, transnational Chinese regional, and Euro-American global music. Favorite Taiwanese artists cited by this sample of Sandee's fans included Faith Yang, Huang Xiaozhen, Chen Qizhen, Tang Na, Patricia Ho, Lei Guangxia and Chen Xiaoxia; the two Hong Kong artists cited were Karen Mok and Faye Wong; the single Singaporean cited was Stefanie Sun; and American and European favorites included Tori Amos, Sinead O'Connor, The Indigo Girls, The Cranberries, Garbage, Alanis Morisette, Vonda Shepard and Lori Carson. This list frames Sandee within the music collections and "taste maps" of this sample of her nütongzhi fans as part of a local, regional and global network of musicians that suggests that while Englishlanguage music clearly has an important presence for these fans, it's nonetheless crucially contextualized by their similar enjoyment of regionally and locally produced music.

Sandee Chan is further differentiated within the category of the "alternative" through the common interpretation of her as a feminist artist. One nütongzhi fan from Taiwan had this to say: 
I've really liked Sandee Chan ever since I was in high school and a friend played me her Four seasons. [...] Now she's a famous musician, but in her music and her thinking she still holds to her own opinions. Maybe that's the reason I liked her as soon as I heard her music. Many of her lyrics are concerned with social critique and feminism, and they give you lots of different points of view to consider.

(written response to survey, March 2001)

This respondent's comments are representative of a linkage most respondents drew between their fandom and Sandee's perceived feminism ${ }^{15}$. As these fans suggest, Sandee's songs and public statements frequently foreground a feminist cultural politics. For example, consider the lyrics of her 1996 song, "Women on this planet," which in linking the refrain of "one planet" with the stated hope for an improvement in women's lives, seem to bespeak a yearning for a globally effective feminism:

I come from Earth without divine assistance.

I'm not praying for peace and prosperity in some future incarnation

But I do hope that in the future women's lives

can be free from fear and anxiety.

I come from one planet

and yearn for a kind of freedom.

(Chan 1996, my translation)

In addition, Sandee has chosen Taipei's Witches' Pub (Nüwudian) as a venue for her live performances, a bar housed on the ground floor of the feminist bookstore, Fembooks (Nüshudian): a choice that betokens a deliberate alignment of her work with Taiwan's vigorous and publicly prominent feminist movement. ${ }^{16}$ But further to her overtly stated feminist politics, for some of her nütongzhi fans Sandee's music also encodes a certain, much less clearly stated lesbian significance. One woman, a Taiwanese student in the USA, gave a compelling account of how Sandee has taken on nütongzhi significance for her as a result of resonances with her own personal life:

One reason [why I think there's a link between Sandee and the topic of nütongzhi] is that my first - and only - partner's voice sounded a lot like Sandee's. When speaking on the phone with her I discovered her voice was very pleasant, just like Sandee's, and it was then that my desire to love women was aroused.

(written response to survey, July 2001)

In this response, the particularly "pleasant-sounding" (haoting) quality of Sandee's singing voice appears to act as a catalyst both for the desire between the respondent and her distant partner on the other end of the phone, and the respondent's recognition of her own queer longing. Such a response demonstrates that the absorption by a particular star of nütongzhi significance for particular listeners is a highly unpredictable process, based on the idiosyncrasies of individual association, memory and desire as much as it is on the ostensible content of a star's image and musical output. The same fan continues:

Another reason [why I think there's a link between Sandee and the topic of nütongzhi] is that I think Sandee is a singer with a female consciousness. Her personal life, her public statements, her essays and song lyrics, her whole image, all have quite a different feel than [those of] a mainstream, heterosexual woman. I think this image has a great capacity to draw my identification.

(written response to survey, July 2001)

Fans' identification with Sandee's image of freethinking independence was another frequently 
cited reason they gave for their fandom. Sandee herself speculates that this may be one reason for her popularity with this audience: "maybe because originally, homosexuals felt they were a minority within society, and at that stage in Taiwan my music was fairly alternative, also a minority thing, they were naturally attracted to it" (Chan n.d., my translation). As another fan put it, "you might say that her bold, unique, marginal style (in contrast with the mainstream market) has attracted many lesbian fans, who are similarly positioned outside of mainstream society." What attracts these particular lesbian fans is, in part, the idea of difference or alternativeness that adheres to Sandee's star image - even while the ambiguous appearance of the lesbian topic in popular music like Sandee's is in fact enabled by the new interiority of this subject to public discourse. ${ }^{17}$

The appeal of Sandee's music to young, tertiary-educated, urban nütongzhi can be partly explained, then, through reference to the shared investment of Sandee and this group of women in a feminist critique of patriarchal social relations, and through the fans' identification with Sandee's star image as a confident, independent and unconventional woman. But I think Sandee's music is itself also particularly amenable to lesbian interpretation and, indeed, many of the respondents told me that, like me, they particularly enjoy Sandee's incisive lyrics.

The song most clearly associated with the subject of lesbianism is Sandee's 1999 song, "Beautiful girl" (Meilide nüsheng). The lyrics of this cheery, up-beat pop song are as follows:

Falling in love with a beautiful girl

Pretty wig

Falling in love with a beautiful girl

Opium scent

Falling in love with a beautiful girl

Artistic nails

Falling in love with a beautiful girl

Nylon stockings.

I want to fall in love with a beautiful girl

No matter what she looks like.

I want to fall in love with a beautiful girl

At this moment.

Falling in love with a beautiful girl

Split skirt

Falling in love with a beautiful girl

Wonder Bra

Falling in love with a beautiful girl

Elegant heels

Falling in love with a beautiful girl

Shhh! Don't speak.

(Refrain)

My love is too much

The elevator won't close

If I turn my eyes I'll lose control

My heart falls nervous of its own accord.

I want the beautiful girl

To live downstairs.

I want the beautiful girl

To move into my place.

I want the beautiful girl 
To look at me.

I want the beautiful girl

to take me home.

(Chan 1999, my translation)

Interestingly, when asked to interpret the degree of lesbian signification encoded in the lyrics of this song, Sandee's nütongzhi fans gave a very mixed response. Answering the question: "Do you think "Beautiful girl is a nütongzhi song?" fans provided the following array of answers:

I don't really think so, but I don't really not think so, either. ... I think girls who aren't nütongzhi are also able to appreciate other girls, so I don't think there's anything strange about it.

I don't think so!

Yes, it is. [Sandee] said so herself. It's very obvious from the lyrics.

[Sandee] said she wrote "Beautiful girl" from the point of view of a boy looking at a girl.

No. Ordinary heterosexual girls can gasp in admiration of a beautiful girl, too!

It could be applied to nütongzhi; I guess it all depends on how the individual interprets it. I think if a woman sings [...] this song, it can be used to express the feelings between two nütongzhi. But if it was sung by a boy, then it's no different from normal heterosexual feeling!

It seems to be the projection of a masculine desire for a woman. Perhaps because I've always heard Sandee's lyrics from a very female, slightly ironic perspective, I haven't interpreted them in a nütongzhi way.

Yes, I think it is! But some people tell me it's just her satirizing the state of contemporary society.

Yes! But I think you could also say no. Because I guess everyone loves a beautiful girl: boys and girls are all attracted by a beautiful girl's loveliness.

(written responses received between March and September, 2001)

What emerges most forcefully from this range of disparate responses is the fans' sophisticated, collective awareness of the ambivalence of the song's representation of the feelings of one "girl" for the other, and its potential for double meaning. Rather than simply claiming the song as a straightforward expression of nütongzhi identity, the fans repeatedly voice the insight that the song is not exactly a nütongzhi song, but not precisely not one, either. ${ }^{18}$ Just as the "Perfect" music video allows for an innocuously straight reading while simultaneously offering points of purchase for nütongzhi decoding, according to these fans' responses, "Beautiful girl" dramatizes that precipitous moment when "an ordinary girl's appreciation of another girl" threatens (or promises, depending on your point of view) to become a desire explicitly linked with the relatively new sexual and political identity nütongzhi.

While the fans indicate that they don't quite agree that "Beautiful girl" is beyond doubt a nütongzhi song, their responses also indicate that as a group they would be dissatisfied with the conclusion that the nütongzhi subject is utterly absent from the lyrics. The question, then, is one about precisely how nütongxinglian inhabits the song's text and its consumption. Listening to the song with that question in mind, the line "Shhh! Don't speak" (Xu! Bie shuohua) stands out immediately, addressing as it does the central problematic of the tension between speech and silence. The only instance of direct imperative address, the line demarcates the first section of the song in which the "beautiful girl" is described from the final section in which the singer describes the intensity of her own reaction to the girl's presence. Paradoxically, then, the anxious directive against speaking is followed by the most direct confession of the singer's 
desire for the other woman, as though the force of the singer's love shatters the disciplinary imperative prohibiting speech in the same way it also precipitates the singer's loss of control over her body ("If I turn my eyes I'll lose control/My heart falls nervous of its own accord") and prevents the elevator door from closing ("my love is too much/The elevator won't close"). Taken together, the fans' ambivalent responses to the question of the nütongzhi significance of the song, and the obtrusive imperative "don't speak," suggest that in both its lyrical content and its interpretation by nütongzhi audiences the song indexes a nütongxinglian marked by a simultaneous reticence and audibility: a reticence and an audibility and a paradoxical audibility in reticence that perhaps replicate the conditions of nütongxinglian's presence in Taiwan's popular music cultures more broadly.

As Liu and Ding (1998) have forcefully argued, the conditions under which tongxinglian subjects subsist in contemporary Taiwan are more often than not conditions of enforced reticence (hanxu) vis-à-vis their sexual preference. How, then, to interpret Sandee's pop musical production of nütongxinglian as subtext, eloquent silence, and connotation: in a word, reticence? Perhaps the most useful questions here are: what kind of hanxu it is that the song exemplifies (since crucially, Liu and Ding observe, following Foucault, there is not one but many reticences) (Liu and Ding 1998: 113)? And: what are the implications of this particular hanxu for understanding the place of nütongxinglian in Mandarin pop music and Taiwan's popular culture more broadly? Insofar as the lesbian content of Sandee Chan's star persona and music function as a subtext available to differential decoding by nütongzhi audiences, the hanxu attaching to the nütongzhi subject in this case seems not to equate to an autocratic, homophobic blanket of silence covering all traces of the subject - as in the disciplinary form of hanxu theorized by Liu and Ding - but sounds more like the various translations of hanxu as a stored-up, concealed yet implicit potentiality. It is this that makes this kind of hanxu ambivalent: it is less a silencing than a different way of speaking: a just-audible speaking by not-quite-saying. Such a mode of speech cannot and should not replace more direct, forthright speech on matters of dissident sexuality, but it may nonetheless provide its own distinct pleasures and possibilities. The subtexting of nütongxinglian in Sandee's music and star persona thus produces a contradictory hanxu: in one sense it obeys the disciplinary command to silence; in another sense it undermines that command through a different kind of speech: in Liu and Ding's terminology, perhaps the auditory equivalent of a "penumbral" representation. This equivocal speech is not the same thing as silence, but is an ambivalent mode of speaking whose critical potential lies largely in the ways it is heard and interpreted by particular listeners.

This ambivalent hanxu, distinct from the disciplinary mode theorized by Liu and Ding, is likely enabled in large part by the distinctiveness of the pop-musical form. ${ }^{19}$ Liu and Ding's argument on the regulatory hanxu that silences tongxinglian is made through a discussion of a literary text: Rebel daughter, the popular novel by Du Xiulan (1996). The novel's realist first-person narrative centers on a young lesbian protagonist, Ding Tianshi, who is caused endless shame on the one hand by her own lesbian desires, and on the other hand by a talkative, working class and decidedly un-reticent mother who subjects her to constant abuse in private and embarrasses her in public with her failure to conform to the standards of polite behavior. Liu and Ding suggest that the novel's harsh judgment of Ding Tianshi's mother reinforces the standard of hanxu both as a marker of polite, middle-class modes of behavior and speech, and as the mode of (non-)speech best befitting the subject of tongxinglian. It is significant that this illustration of hanxu as disciplinary tool for regulating hierarchies of class and sexuality is found in a popular psychological-realist novel: a form of cultural production whose generic requirements for a developmental narrative moving toward closure, and clearly delineated characters, may contribute to the decisiveness of this novel's unequivocal treatment of both nütongxinglian and hanxu. The pop-musical form, though, with its short, allusive and poetically structured songs, and the tendency for lyrics to be only half-heard, or overheard while the listener is engaged in some other activity, provides a marked contrast to the novel form. The 
ephemerality, elusiveness, and openness of a pop song's narrative and meaning are crucial in enabling the production of a looser and more ambiguous form of reticence on tongxinglian.

Perhaps Sandee's nütongzhi potentiality finds an echo in the idea of the "perfect lie" whose meaning "depends on how you say it." (The Chinese phrase - jiu kan ni zenme shuo - means literally "one then has to look at how you say it." Its sense might be rendered in more colloquial English: "depending on how you look at it," though in this context, the centrality of the act of speaking in the Chinese phrase should not be overlooked.) Gazing after the other woman in the song's music video, Sandee sings, "If you love me, I beg you: tell me/Tell a perfect lie": Is the imagined lie perfect because it works as successful alibi and excuse, hoodwinking the lover and dissimulating love (I say I love you, when really I do not)? Or is it perfect because in it is audible the encoded confession of an actual love (I say I do not love you, when really I do)? Once again, these questions are undecidable: the overall, hazy impression is that there seems to be some love there somewhere - perhaps. In its volatility and affective charge, the penumbral love that shadows the perfect lie might work as a figure for the chimerical co-presence of nütongzhi meaning in Mandarin pop music culture more broadly.

The equivocal voicing of nütongxinglian in Sandee's music lacks the direct force of lesbian statement in the work of avowedly nütongzhi bands like Bang-bang Mang. Nevertheless, it indexes the fullness of a half-heard lesbian potentiality that is capable of saturating popular culture with a thoroughness that countercultural representations, by definition, cannot achieve. As observed above, pop music is probably the form that most thoroughly permeates the fabric of Taiwan's cultural life, Mandarin and Minnan pop music accompanying one's every move through the spaces of the city with a thoroughness impossible for other cultural forms. In doing this, Sandee's music and that of other performers with various degrees of lesbian subtext underlying their star images projects the oddly audible reticence of nütongxinglian throughout the audioscapes of everyday culture, from the public cacophony of night market ghetto blasters playing the hits of Pan Meichen and Faye Wong to solitary moments of headphone listening to Stefanie Sun or Sandee Chan. As an adjunct to nütongzhi musical countercultures, one might say that lesbian pleasure in Mandarin pop enables nütongzhi to become momentarily deaf to the loudspeakers of heterosexist popular culture (to take liberties with Chow's phrase). More than this, nütongzhi listening in a sense infiltrates the loudspeaker of the popular itself, making it a mechanism through which nütongzhi signification voices its ubiquitous presence in the auditory environment of the everyday.

Pop musical hanxu on nütongxinglian, then, serves a contradictory function. As a form of silencing, it acts in the conservative way that Liu and Ding describe, in concert with heterosexist cultural power to deny the nütongzhi subject a legitimate, fully public speaking position. But as a form of encoded speech and a differential listening practice, this particular manifestation of hanxu also does precisely the opposite, demonstrating pop music's ineluctable complicity in transmitting the static interference of nütongzhi difference and dissent. Mandarin pop like Sandee's thus contributes to the production of nütongxinglian in contemporary Taiwan as a formation organized by an ambivalent reticence. Like the lyrics of Sandee's song, this music tells its nütongzhi audiences the perfect lie: at once an equivocating excuse, and the yearned-for expression of an almost unspeakable love.

\section{Notes}

1. Nütongzhi means literally "female comrade," but since the early 1990s has functioned as a neologism denoting, approximately, "lesbian." Tongzhi is used to mean either "gay" or "gay and lesbian." I retain the linguistic specificity of the term nütongzhi in this paper to signal the embeddedness of nütongzhi within particular cultural and historical contexts that mark its variance from the modern EuroAmerican construction of "lesbian."

2. This paper takes as its starting point the important observations about the discourse of reticence (hanxu) in relation to tonxinglian (homosexuality) put forward by Jenpeng Liu and Naifei Ding (1998). 
3. The International Federation of the Phonographic Industry found that Taiwan's total album sales in the first half of 1999 reached 18 million units, generating US\$167.7 million. In the same period mainland China posted a market value of just US $\$ 46.4$ million, and total album sales in this period were just over 2 million units in Singapore, and 4.7 million in Hong Kong. (Taipei Review, 2000) Domestically, Taiwan's popular music market is divided between songs in Minnan (Taiyuge), the local variant of Hokkien, and songs in Mandarin (Guoyuge). Taiyuge are often interpreted as carrying connotations of Taiwanese localist resistance to the hegemony of Mandarin-speaking mainlander immigrant culture. For a discussion of the cultural politics of Taiyuge see Taylor (forthcoming).

4. But see Wang (1997), Parry (2000; 2001), Witzleben (1999), Gold (1993), and Chen (n.d).

5. See also Stokes' (1999) incisive critique of the reification of "subversion" in English-language scholarship on mainland Chinese rock, exemplified by Jones' Like a Knife: Ideology and Genre in Contemporary Chinese Popular Music (1992).

6. For example, see Yuanyuan Broadcasting Planning Committee (1996): a book of transcripts from a tongzhi radio program of the same name.

7. Thanks to Audrey Yue for bringing to my attention an occasion she attended at a lesbian bar in Singapore in 2001 in which patrons enthusiastically sang along to this song while the Karaoke video clip screened in the background.

8. For example, a shot of the man placing a crown woven from flowers on the other woman's head cuts to a shot of the crown falling down on Sandee's head, implying that the other woman has replaced Sandee as the object of the man's affections.

9. For a discussion of how the ambiguities of gender positioning in MTV uniquely enable a "gay gaze," see Drukman (1995).

10. It should be noted, though, that the audience for much of the new tongzhi culture remains quite limited. In the case of avant-garde queer fiction and film, the audience is largely restricted to the educated, urban middle-class. The fact that queer stories and films enjoy prominence in the intellectual cultures of northern Taiwan does not translate into any widespread acceptance of gay and lesbian individuals, and much of the media buzz around tongzhi cultures remained markedly homophobic.

11. See the discussion among Taiwan and Hong Kong lesbians on the possible $\mathrm{T}$ (Tomboy) lesbian identity of Singaporean Mandarin pop star Stefanie Sun, between July and September 2001. (Gaystation n.d. a)

12. Liu and Ding (1998) argue that a discourse of reticence can be traced through a Chinese literary and moral tradition. However, the authors disagree with Hong Kong sociologist Chou Wah-shan's reification and uncritical celebration of such a "Chinese tradition" in his book, Houzhimin Tongzhi (1997). While Chou celebrates a culturally essentialist view of "silent tolerance" as "the Chinese way," Liu and Ding point out that exhortations to hanxu in practice work conservatively, against the interests of tongzhi.

13. Thanks to Teri Silvio for providing the Minnan transliteration of this song title. For a related discussion, see Chang Hsiao-hung (1993).

14. I am once again indebted to the generous assistance of Josette Thong (Tang Jiayue) in refining my translation of the questionnaire and posting it at local Taiwan BBS sites. Many, many thanks, too, to all the questionnaire respondents.

15. For a fuller discussion of Sandee's feminist image, see Martin (forthcoming 2003b).

16. Sandee's eagerness publicly to claim a feminist politics, compared with her sometimes ambivalent attitude toward her lesbian fans is perhaps telling in its suggestion of the far broader public acceptance of the feminist as against the tongzhi movement.

17. Again, the limited character of the audience demographic reached with this survey must be emphasized here. While particular fans, and Sandee herself, construct Sandee's lesbian fandom as based on a shared significance of "outsiderness," it is by no means the case that all Taiwanese lesbians become attracted to Sandee's music as a result of suffering outsider status. In fact, many T bar DJs favor mainstream Mandarin and Minnan pop music over the new singer-songwriter sound of artists like Sandee, and it is evident that many factors other than sexuality-including regional location, first language, ethnicity, class affiliation, level of education, generation, etc-may play an important role in influencing any given individual's taste in music.

18. Although one fan does cite "Beautiful Girl" as one of her favorite songs "because I think about beautiful girls, too."

19. Many thanks to Amie Parry for her suggestions on this point, and for engaging with me in a very helpful discussion on reticence and the novel form.

\section{References}

Anonymous (n.d.) 'You can't ignore Sandee Chan' 不能忽略陳㴬始，＜http://www.geocities.com/ SunsetStrip/Balcony/5605/album.htm >, accessed 17 August 2000. 


\section{F. Martin}

Becker, Edith, Michelle Citron, Julia Lesage and B. Ruby Rich (1995) 'Lesbians in film'. In Corey K. and Alexander Doty (eds.) Out in culture: Gay, lesbian and queer essays on popular culture, Durham and London: Duke University Press, 25-43

Berry, Chris and Fran Martin (2003) 'Syncretism and synchronicity: Queer'n'Asian cyberspace in 1990s Taiwan and Korea'. In Chris Berry, Fran Martin and Audrey Yue (eds.) Mobile Cultures: New Media and Queer Asia, Durham and London: Duke University Press.

Bradby, Barbara (1993) 'Lesbians and popular music: Does it matter who is singing?' In Gabrielle Griffin (ed.) Outwrite: Lesbianism and popular culture, London and Boulder: Pluto, 148-171.

Castle, Terry (1993) The apparitional lesbian: Female homosexuality and modern culture, New York: Columbia University Press.

Chan, Sandee 陳珊妮 (1996) Four seasons 四季末的唱避, Taipei: Friendly Dogs 友善的狗.

Chan, Sandee (1999) Humor? 我㹱兆不是幽默的女生，Taipei: Friendly Dogs 友善的独。

Chan, Sandee (2000) Perfect moan 完美的呻吟, Taipei: Magic Stone 魔岩。

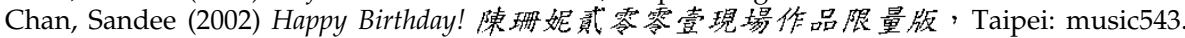

Chan, Sandee (n.d.) Interview, < http://www.gaystation.com.hk/leisure/events_sandee.html > , accessed 3 July 2001.

Chang, Hsiao-hung 張小虹 (1993) 'Red boys and green girls: Love songs, popular culture and gender subversion' 紅男綠㚣: 情歌、流行文化與性别顛覆, Postmodern/women: power, desire and gender

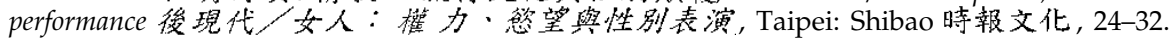

Chang, Hsiao-hung (1998) 'Taiwan queer valentines'. In Kuan-hsing Chen (ed.) Trajectories: Inter-Asia culutral studies, London and New York: Routledge, 294-96.

Chao, Antonia Yengning 趙彦旁 (1996) 'Embodying the invisible: Body politics in constructing contemporary Taiwanese lesbian identities', Ph.D. diss., Cornell University.

Chou, Wah-shan 周華山 (1997) Postcolonial tongzhi 後殖民同志, Hong Kong: Xianggang Tongzhi Yanjiushe 香港同志研究社.

Chen Chun-bin (n.d.) 'Remapping Taiwan musically: the use of translocal/transnational elements and the narratives of local experience in Jutopi's music', <http://www.ucla.edu/ccs/paper/TW_Chen_ Chun-bin.pdf $>$, accessed 8 November 2001.

Chi, Ta-wei 紀大偉 (1997) 'Queer theory: A consideration of queerness and queer fiction in contemporary Taiwan'酷兒論：思考党代台灣酷兒與酷兒文學. In Chi Ta-wei (ed.) Queer

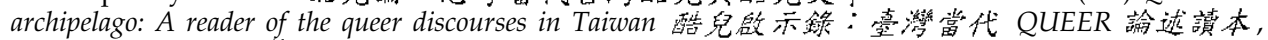
Taipei: Yuanzun 元尊文伦，9-16.

Chow, Rey (1993) Writing diaspora, Bloomington: University of Indiana Press.

Creekmur, Corey K (1995) 'Introduction'. In Corey K. Creekmur and Alexander Doty (eds.) Out in culture: Gay, lesbian and queer essays on popular culture, Durham and London: Duke University Press, 403-406.

Creekmur, Corey K. and Alexander Doty (eds.) (1995) Out in culture: Gay, lesbian and queer essays on popular culture, Durham and London: Duke University Press.

‘Dragon goddess in a bitter sea' 苦海女神龍 (1994) excerpted on the cover of Ai Bao 愛堆 2 (June 1994).

Drukman, Steven (1995) 'The gay gaze, or why I want my MTV'. In Paul Burston and Colin Richardson (eds.) A queer romance: Lesbians, gay men and popular culture, London and New York: Routledge, $81-95$.

Dyer, Richard (1995) 'In defence of disco'. In Corey K. and Alexander Doty (eds.) Out in culture: Gay, lesbian and queer essays on popular culture, Durham and London: Duke University Press, 407-415.

Du Xiulan 杜修蘭 (1996) Rebel daughter 朔女, Taipei: Huangguan 皇冠.

Gaystation (n.d. a) message board, < http://www.gaystation.com.hk/amb/girlie/1069.html > , accessed 15 September 2001

Gaystation (n.d. b) 'Watch Sandee, listen to the moan' 看俩妮，聽呻吟，<http://www.gaystation. com.hk/leisure/events sandee.html>, accessed 3 July 2001.

Gold, Thomas B. (1993) 'Go with your feelings: Hong Kong and Taiwan popular culture in greater China', The China Quarterly 136 (Dec): 907-925.

Jian Jia-Shin 簡家欣 (1997) 'Bring out Taiwan lesbians: The lesbian discourses and movements in

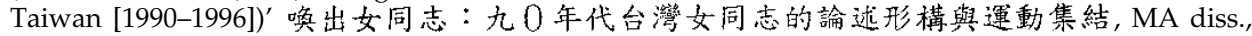
National Taiwan University.

Jones, Andrew (1992) Like a knife: Ideology and genre in contemporary Chinese popular music, Ithaca: Cornell East Asia Series.

Liu Jenpeng and Ding Naifei 劉人鹏，丁乃非 (1998) 'Reticent poetics, queer politics' 同兩問景：含蓄美學與酷兒政略，Working papers in gender/sexuality studies 性／别研究 3-4 (September): 109-155.

Lu Mei 露繁 (1994) 'Vixen, distant lands, dragon goddess: On lesbian cultural praxis' 妖精，買鄉， 女神龍：談女同性戀的文伦賽踐，Ai Bao 愛報 2: 13-14. 
Martin, Fran (1999) 'Chen Xue's queer tactics', Positions: East Asia cultures critique 7(1): 71-94.

Martin, Fran (2000) 'Surface tensions: Reading productions of tongzhi in contemporary Taiwan', GLQ 6(1): 61-86.

Martin, Fran (2003) The emergence of Taiwan's literature of transgressive sexuality'. In Fran Martin (ed. and trans.) Angelwings: Contemporary queer fiction from Taiwan, Honolulu: University of Hawaii Press, 1-28.

Martin, Fran (forthcoming 2003b) 'Women on this planet: globalization and girl rock in Taiwan'. In Tony Mitchell (ed.) Liminal sounds and images: Transnational Chinese popular music, Hong Kong University Press.

Parry, Amie (2000) 'Narcissism and a catechism: Flashing objects in contemporary music culture', paper presented at the conference 'Alternative questions about female subjectivity' part 2 (National Taiwan Central University, Center for the Study of Sexualities, 26 November).

Parry, Amie (2001) 'Narcissists, lesbians, shuai T's and so on: The cultural politics of creative taxonomies', Triangle Park 3 (May) < http://www.ncu.edu.tw/ eng/csa/journal/journal_park13.htm >, accessed 16 May 2001.

Pizi 㾂子 (n.d.) 'Lez talk: A brief history of Taiwan lesbian and gay movement'台灣 同志運動簡史：九零年代前半，＜http://www.to-get-her.org/column/history/GayMovement2. shtml $>$, accessed July 262002.

Seidman, Steven (1995) 'Deconstructing queer theory or the under-theorization of the social and the ethical'. In Linda Nicholson and Steven Seidman (eds.) Social postmodernism: Beyond identity politics, Cambridge: Cambridge University Press, 116-141.

Stein, Arlene (1995) 'Crossover dreams: Lesbianism and popular music since the 1970s'. In Corey K. Creekmur and Alexander Doty (eds.) Out in culture: Gay, lesbian and queer essays on popular culture, Durham and London: Duke University Press, 416 - 426.

Stokes, David (1999) 'Chinese rock in the Western eye', antiTHESIS (10): 86-103.

Taipei Review (2000) < http://www.taiwanheadlines.gov.tw/20000426/20000425f2.htm > (26 April), accessed 20 August 2001.

Taylor, Jeremy (forthcoming December 2003) 'Pop music as post colonial nostalgia in Taiwan'. In Allen Chun, Ned Rossiter and Brian Shoesmith (eds.) Refashioning pop music in Asia: Cosmopolitan flows, political tempos, and aesthetic industries, Surrey: Curzon Press.

Tongzhi Hotline 同志資詢熟線 (n.d.) '1999 Tongzhi Hotline fundraising party' 1999 同志資詢熱線募款睌會，＜http://www.hotline.org.tw/hotline/donate-1999party.htm＞，accessed 1 June 2001.

Tongzhi Space Alliance 同志空間行陲陣線 (1996) Flier, '10 great tongzhi lovers vote' 1996 同志十大情人需選活動.

Wang, Georgette (1997) 'Seeking the best integration: Popular music in Taiwan'. In Alison J. Ewbank and Fouli T. Papageorgiou (eds.) Whose master's voice? The development of popular music in thirteen cultures, Westport and London: Greenwood, 209-220.

Witzleben, J. Lawrence (1999) 'Cantopop and Mandapop in pre-postcolonial Hong Kong: identity negotiation in the performances of Anita Mui Yim-Fong', Popular music (18:2): 241-257.

Wong, Victor (1998) 'Live from Taiwan', Billboard, 110(32) (August 8): APQ-1.

Wong, Victor (1999) 'Taiwan unseats Hong Kong as a new music centre', Billboard, 111(32) (August 7): APQ-1-2.

Yuanyuan Broadcasting Planning Committee 線圓傅播企畫小組 (1996) Tongzhi lover 愛人同志， Taipei: Jin Boluo 金菠維.

\section{Special terms and names:}

Ai Bao 愛埾

airen tongzhi 愛人同志

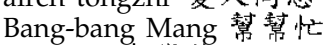

budai xi 布袋戲

Chen Qizhen 堜绮真

Chen Xiaoxia 陳小霞

hanxu 含蓄

haoting 好聽

Ho, Patricia 何欣穗

Huang Xiaozhen 金菠維

jiu kan ni zenme shuo 就看你怎麼説

kho hai lu sim liong 苦海女神龍

koa-a-hi 歌仔戲
Lei Guangxia 雷光夏

Meilide Nüsheng 美麗的女生

Mok, Karen 篹文蔚

Ninü 逆女

Nüshudian 女書店

nütong mingren 女同名人

nütongxinglian 女同性戀

nütongzhi 女同志

Nüwudian 安巫店

ruo yin ruo xian 若鲑若現

Sun, Stefanie 㧠燕溇

Taiyuge 台䛇歌

Tang Na 娜 


\section{F. Martin}

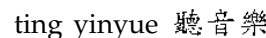

tongxinglian 同性戀 tongzhi 同志

tongzhi airen 同志愛人

Wanmei 完美
Wong, Faye 王菲

Xu! Bie shuohua 嘘！別說話

Yang, Faith 禓 73 文

zhi tongzhi 直同志

\section{Author's biography}

Dr Fran Martin is Lecturer in Cinema Studies at La Trobe University, Australia. She has published articles on queer culture and politics in Taiwan in journals including Positions, GLQ, Intersections, Critical InQueeries, Communal/Plural and Chung-wai literary monthly. Her book, Situating sexualities: Queer representation in Taiwanese fiction, film, and public culture Hong Kong University Press (2003), and her edited collection of her own translations, Angelwings: Contemporary queer fiction from Taiwan the University of Hawai'i Press (2003). She is co-editor with Chris Berry and Audrey Yue of Mobile cultures: New media and queer Asia, Duke University Press (2003). Her current research project investigates lesbian representation in the transnational Chinese popular cultures that span Hong Kong, Taiwan and the People's Republic of China. 


\section{University Library}

\section{- M M I N E R VA A gateway to Melbourne's research publications}

Minerva Access is the Institutional Repository of The University of Melbourne

Author/s:

MARTIN, F

Title:

The Perfect Lie: Sandee Chan and lesbian representability in Mandarin pop music

Date:

2003

Citation:

MARTIN, F. (2003). The Perfect Lie: Sandee Chan and lesbian representability in Mandarin pop music. Inter-Asia Cultural Studies, 4 (2), pp.264-280

Persistent Link:

http://hdl.handle.net/11343/25286 